\title{
Hormonal Regulation of CREB Phosphorylation in the Anteroventral Periventricular Nucleus
}

\author{
Guibao Gu, ${ }^{1}$ Anthony A. Rojo, ${ }^{1}$ Michele C. Zee, ${ }^{1}$ Jianhua $Y u,{ }^{1}$ and Richard B. Simerly ${ }^{1,2}$ \\ 1 Division of Neuroscience, Oregon Regional Primate Research Center, Beaverton, Oregon 97006, and 2Program in \\ Neuroscience, Oregon Health Sciences University, Portland, Oregon 97201
}

The anteroventral periventricular nucleus (AVPV) is a nodal point in neural circuits regulating secretion of gonadotropin and contains sexually dimorphic populations of hormonally regulated dopamine-, dynorphin-, and enkephalin-containing neurons. Because the tyrosine hydroxylase $(\mathrm{TH})$, prodynorphin (PDYN), and proenkephalin (PENK) genes contain CAMP response elements that control their expression in their promoters, we used histochemical methods to determine whether ovarian steroids alter expression of the CAMP response element-binding protein (CREB) in the AVPV. Because the ability of CREB to activate transcription depends on phosphorylation at $\operatorname{Ser}^{133}$, we also evaluated the effects of acute steroid treatment on levels of phosphorylated CREB (pCREB) in AVPV neurons by using an antibody that differentiates between CREB and PCREB. Treatment of ovariectomized rats with estradiol treatments caused a significant induction in the number of
pCREB-immunoreactive nuclei within $30 \mathrm{~min}$ that was maintained for at least $4 \mathrm{hr}$, but did not alter CREB immunostaining in the AVPV. Pretreatment with the estrogen antagonist Nafoxidine blocked this induction. In contrast, acute administration of progesterone to estrogen-primed animals suppressed and then increased PCREB staining in the AVPV at 30 and $60 \mathrm{~min}$, respectively; no significant differences between experimental and control animals were apparent by $2 \mathrm{hr}$ after progesterone treatment. Double-labeling experiments showed that pCREB was colocalized with PDYN, PENK, or TH mRNA in the AVPV, suggesting that $P C R E B$ may mediate the effect of steroid hormones on gene expression in these neurons.

Key words: anteroventral periventricular nucleus; preoptic region; CAMP response element-binding protein; immunohistochemistry; ovarian steroids; estrogen; progesterone
A unique function of the hypothalamus is its role in integrating both somatic and visceral sensory information with hormonal status to influence secretion of hormones such as luteinizing hormone and prolactin from the anterior pituitary (for review, see Swanson, 1987; Simerly, 1995a). The anteroventral periventricular nucleus of the preoptic regions (AVPV) is a critical component of neural circuits that regulates gonadotropin secretion and represents an important site for hormone feedback on gonadotropinreleasing hormone (GnRH) neuronal function (for review, see Simerly, 1995b). The AVPV contains one of the highest densities of neurons that express estrogen or progesterone receptors in the mammalian forebrain (for review, see Simerly, 1993; Simerly, 1995b) and receives strong inputs from other sexually dimorphic forebrain regions that are hormone-sensitive, such as the principal nucleus of the bed nuclei of the stria terminalis and the medial preoptic nucleus (Simerly and Swanson, 1988; Simerly et al., 1989; Canteras et al., 1992a,b; Canteras et al., 1995). Thus, the function of neurons in the AVPV can be regulated by estrogen or progesterone via a direct action mediated by their cognate receptors, or regulated transsynaptically through projections from other hormone-sensitive regions.

Received Nov. 6, 1995; revised Feb. 6, 1996; accepted Feb. 9, 1996.

This work was supported by National Institutes of Health Grants NS26723, RR00163, and HD18185. This is publication No. 1981 of the Oregon Regional Primate Research Center. We thank Dr. M. S. Smith for kindly providing RU 486, Dr. D. Hess for steroid hormone RIAs and Ms. C. Houser for preparation of this manuscript. We are also grateful to Dr. R. H. Goodman for the gift of CREB and pCREB proteins.

Correspondence should be addressed to R. B. Simerly, Oregon Regional Primate Research Center, 505 N.W. 185th Avenue, Beaverton, OR 97006.

Copyright (C) 1996 Society for Neuroscience $0270-6474 / 96 / 163035-10 \$ 05.00 / 0$
Although primarily thought of as nuclear transcription factors that alter patterns of gene expression, steroid hormone receptors, or steroid hormone-binding proteins very similar to these receptors, also exert rapid effects on neuronal activity that cannot bc explained purely by genomic mechanisms (Kelly, 1982; Harrison et al., 1989; Schumacher, 1990; Wong and Moss, 1992). One way steroid hormones could effect such changes in neuronal signaling is by altering signal transduction pathways associated with second messengers, such as calcium and cAMP. Estrogen and progesterone influence gene expression in mammary carcinoma cells by altering the activity of adenylate cyclase and protein kinase $\mathrm{C}$ (Denner et al., 1990; Beck et al., 1992; Cho and Katzenellenbogen, 1993; Aronica et al., 1994), and the same signaling pathways may be hormonally regulated in neurons (Petitti and Etgen, 1990; Kow et al., 1994).

The cAMP response element-binding protein (CREB) is a constitutively expressed transcription factor that is present in most hypothalamic neurons and has been shown to activate well characterized neuropeptide genes (Goodman, 1990; Armstrong and Montminy, 1993). It acts primarily by binding to calcium-cAMP enhancer elements in the promoter region of cAMP-responsive genes, and either increases or deceases transcriptional activity depending on a variety of molecular factors, such as proximity to adjacent regulatory elements or complex protein-protein interactions with coactivators and other nuclear transacting factors (Chrivia et al., 1993; Meyer and Habener, 1993; Delmas et al., 1994; Kwok et al., 1994). Cellular signaling mechanisms that alter either cAMP or calcium levels can activate phosphorylation of CREB, which is required for CREB to become a transcriptional regulator (Gonzalez and Montminy, 1989). Thus, phosphorylation 
of CREB at $\operatorname{Ser}^{133}$ by calcium-calmodulin-dependent protein kinase, or by protein kinase $\mathrm{A}$, appears to determine whether CREB influences expression of genes that contain calcium-cAMP response elements (Ginty et al., 1992; Armstrong and Montminy, 1993).

In the present study, we used the AVPV as a model system to investigate the acute effects of estrogen and progesterone on CREB. Previously, we identified sexually dimorphic populations of dopamine-, enkephalin-, and dynorphin-containing neurons in the AVPV that develop under the influence of sex steroid hormones and appear to be regulated by ovarian steroids in adults (Simerly et al., 1988; Simerly, 1989, 1991). Moreover, tyrosine hydroxylase (TH), proenkephalin (PENK), and prodynorphin (PDYN) genes contain cAMP-responsive sequences in their promoters that bind CREB (Borsook et al., 1994; Cole et al., 1995; Lazaroff et al., 1995), and cAMP has been shown to regulate their expression in vitro (Lewis et al., 1987; Douglass et al., 1994). Therefore, estrogen or progesterone may influence TH, PENK, and PDYN expression in the AVPV by altering cAMP signaling, which may involve regulating CREB activity. The present histochemical study was undertaken to determine whether estrogen or progesterone alter expression of CREB in the AVPV. Because the ability of CREB to activate transcription is dependent on phosphorylation of Ser ${ }^{133}$, we also evaluated the effects of acute estrogen treatment on levels of phosphorylated CREB (pCREB) in AVPV neurons in vivo by using an antibody that differentiates between CREB and pCREB (Ginty et al., 1993). Moreover, we used a combined immunohistochemical in situ hybridization method to determine if hormonally inducible pCREB is expressed in TH, PENK, or PDYN mRNA, which would support the possible involvement of CREB phosphorylation in the hormonal regulation of gene expression in the AVPV.

\section{MATERIALS AND METHODS}

Animals. Adult female Sprague-Dawley rats were obtained from B \& K Universal and housed on a 14:10 light/dark schedule with light on at 5 A.M. Food and water were available ad libitum.

Experiment 1: estrogen and anti-estrogen treatment. Animals were ovariectomized bilaterally on day 65 of life. Seven days after ovariectomy, six pairs of rats were perfused at each of the following time points: 5,15 , and $30 \mathrm{~min}$, and 1 or $4 \mathrm{hr}$ after treatment. Thus, for each pair of animals one received a subcutaneous injection of estradiol benzoate (EB) in $0.2 \mathrm{ml}$ of corn oil $(100 \mu \mathrm{g} / \mathrm{kg})$, and the other received an injection of corn oil alone. This procedure was repeated until 10 groups of animals ( 3 animals/group) were prepared. The EB treatment used in this experiment has been proven to provide rapidly achieved supraphysiological levels of hormone in plasinla and to induce c-fos gene expression in several brain regions, including AVPV (Insel, 1990). However, this hormone treatment model does not replicate a particular aspect of the normal physiological state of intact animals, but is designed to optimize the detection of hormonal effects on cellular responses. To test the specificity of the EB treatment, a separate experiment was performed in which the anti-estrogen Nafoxidine (Sigma, St. Louis, MO) was injected intraperitoneally ( $4 \mathrm{mg}$ in $0.4 \mathrm{ml}$ $0.15 \mathrm{M}$ saline) into 10 ovariectomized female rats. Twenty-four hours later the animals received subcutaneous injections of either EB $(100 \mu \mathrm{g} / \mathrm{kg})$ or corn oil and were perfused $4 \mathrm{hr}$ after injection. This treatment paradigm has been shown by Wade and Blaustein (Wade and Blaustein, 1978) to block estrogen binding in hypothalamic neurons and to block behavioral responses to EB treatment.

Experiment 2: administration of progesterone and RU486. Rats weighing 240-260 gm were ovariectomized $5 \mathrm{~d}$ after their arrival and $8 \mathrm{~d}$ later received subcutaneous implant of silastic capsules of $17 \beta$-estradiol (in corn oil $150 \mathrm{mg} / \mathrm{ml}$, tubing internal diameter $0.16 \mathrm{~cm}$; outer diameter 0.32 $\mathrm{cm} ; 2 \mathrm{~cm}$ in length). Forty-eight hours after implantation, the animals received subcutaneous injections of progesterone $(1.5 \mathrm{mg}$ in $0.2 \mathrm{ml}$ of corn oil), or corn oil only, and were killed by perfusion at 5,15 , and 30 min, and $1,2,4$, or $24 \mathrm{hr}$. This hormonal treatment model has been shown to reliably produce a dramatic surge in luteinizing hormone (LH) secre- tion within a few hours (Wise et al., 1981) and, in our experiments, nearly all of the animals showed marked elevations in serum LH levels. A separate experiment was also performed using the same paradigm, except that animals received subcutaneous injections of the progesterone receptor antagonist RU486 (1 mg in $0.1 \mathrm{ml}$ of corn oil; Center de Recherches, Roussel UCLAF, Paris, France), or corn oil only, $12 \mathrm{hr}$ before progesterone administration. Animals were then perfused at $30 \mathrm{~min}$ and $1 \mathrm{hr}$ after treatment. This experiment was designed to confirm the effect of progesterone on the phosphorylation of CREB in the AVPV, and the dose and time course of RU486 injection have been proven to be physiologically effective (Smith et al., 1989).

Tissue preparation and immunocytochemistry. In each experiment, animals were perfused on the same day. Each rat was deeply anesthetized with tribromoethanol and perfused within 2 min of anesthesia. A 1-2 ml blood sample was rapidly collected from the right atrium of the heart immediately before perfusion. The fixation method follows that described by Hoffman et al. (1992). After a brief rinse with normal saline (50-100 $\mathrm{ml}$ ), each animal was perfused transcardially with ice-cold $1 \%$ paraformaldehyde (Electron Microscopy Sciences, Fort Washington, PA) in 0.1 M sodium phosphate buffer containing $2 \%$ acrolein (EM grade, Polysciences, Warrington, PA) at $\mathrm{pH} 6.8$ for no $>15 \mathrm{~min}$, followed by $100 \mathrm{ml}$ of saline rinse for $\sim 5 \mathrm{~min}$. The brains were quickly removed and placed overnight in $25 \%$ aqueous sucrose. Twenty-micrometer-thick frozen sections through the AVPV of each brain (at a frequency of 1 in 4) were collected in chilled $0.02 \mathrm{M}$ potassium PBS (KPBS). The sections were then incubated in $1 \%(\mathrm{w} / \mathrm{v})$ sodium borohydride in KPBS for $15 \mathrm{~min}$ and rinsed thoroughly in KPBS. Free-floating sections were incubated in anti-rat CREB and anti-rat pCREB primary antisera (raised in rabbit; Upstate Biotechnology, Lake Placid, NY; lot Nos. 12174 and 11975, respectively) at $4^{\circ} \mathrm{C}$ with constant agitation for $72 \mathrm{hr}$. The characterization and specificity of the pCREB and CREB antibodies used in this study have been described previously (Ginty et al., 1993). The pCREB antibody is affinitypurified with a column containing unphosphorylated CREB and is specific for CREB phosphorylated on Ser ${ }^{133}$. The anti-CREB recognizes CREB, but not other members of the CREB/ATF family. Absorption tests on cultured cells showed that no nuclear immunoreactivity was detected when the anti-pCREB primary antibody was preabsorbed with synthetic pCREB (Ginty et al., 1993). In addition to these published reports, we tested the specificity of the staining we achieved by carrying out liquid-phase absorption control experiments by using purified CRER and phosphorylated CREB proteins (provided by $M$. Laurance and R. Goodman, Vollum Institute, Portland OR). Preabsorption of the CREB antiscrum with CREB protcin $(20 \mu \mathrm{M})$ blocked CREB immunorcactivity in nuclei of AVPV neurons, but preabsorption of the pCREB antiserum with the same concentration of CREB had no significant effect on the density of pCREB-immunoreactive nuclei in the AVPV of female rats treated for $2 \mathrm{hr}$ with EB. pCREB staining in adjacent sections from these animals was blocked by addition of phosphorylated CREB protein (12 $\mu \mathrm{M})$ to the pCREB antiserum before staining. Because a different lot number of the pCREB antiserum (lot No. 12994) was used for experiment 2 , the overall density of the pCREB-immunoreactive nuclei in the rat brain in this experiment was notably lower than that in experiment 1 , although the distribution of the pCREB staining was virtually identical in the two experiments. This difference in staining intensity might also be attributable to the lower affinity of the antibody in the second lot. The CREB and pCREB antibodies were diluted to 1:2500 and 1:4000 (lot No. 11975 ) or 1:1500 (lot No. 12994), respectively, in KPBS that contained $2 \%$ normal goat serum and $0.3 \%$ Triton X-100. After brief rinses in KPBS with $0.3 \%$ Triton $\mathrm{X}-100$, the sections were then incubated at room temperature in a biotinylated goat anti-rabbit $\mathrm{IgG}$ secondary antiserum (Vector Laboratories, Burlingame, CA). The sections were rinsed in KPBS and incubated in the avidin-biotin complex (ABC) solution (Vector) at room temperature, and the incubations in the secondary antiserum and $\mathrm{ABC}$ solution were repeated, followed by several rinses in KPBS. The sections were then color-reacted with $0.03 \%$ diaminobenzidine (Sigma), $2.5 \%$ nickel ammonium sulfate, $0.2 \% \mathrm{D}$-glucose, and $0.04 \%$ ammonium chloride in $0.1 \mathrm{M}$ acetate buffer. All sections in each experiment were stained at the same time in the same solutions to avoid systemic technical errors.

In situ hybridization. Animals were perfused transcardially with ice-cold $4 \%$ paraformaldehyde in $0.1 \mathrm{M}$ borate buffer at $\mathrm{pH} 9.5$, after which the brains were quickly removed and post-fixed overnight at $4^{\circ} \mathrm{C}$ in the same fixative containing $20 \%$ sucrose. Twenty-micrometer-thick frozen sections (at a frequency of 1 in 4) through the AVPV of each brain were collected in chilled $0.02 \mathrm{M}$ KPBS that contained $0.25 \%$ paraformalde- 
hyde, $\mathrm{pH} \mathrm{7.4,} \mathrm{and} \mathrm{mounted} \mathrm{onto} \mathrm{gelatin-subbed,} \mathrm{poly-L-lysine-coated}$ microscope slides from the same buffer, but lacking the paraformaldehyde. After a $30 \mathrm{~min}$ proteinase $\mathrm{K}$ digestion $\left(10 \mu \mathrm{g} / \mathrm{ml}\right.$ at $\left.37^{\circ} \mathrm{C}\right)$ and acetylation ( $0.0025 \%$ at room temperature), the sections were dehydrated in ascending alcohols and dried under vacuum overnight. The hybridization procedures used here are based on those reported by Cox et al. (1984) and are described in detail elsewhere (Simmons et al., 1989; Simerly et al., 1990). Briefly, T7 polymerase was used to transcribe ${ }^{35}$ S-labeled antisense cRNA probes from a 416 bp HindIII-StuI fragment of plasmid pGEM7z, a fragment complementary to the $5^{\prime}$ coding region of rat CREB, provided by Dr. Kelly Mayo (Northwestern University, Evanston, IL). The radiolabeled cRNA probe was purified by passing the transcription reaction solution over a Sephadex G-50 Nick column (Pharmacia), and four $100 \mu \mathrm{l}$ fractions were collected and counted by using a scintillation counter. The leading fraction was heated at $65^{\circ} \mathrm{C}$ for $5 \mathrm{~min}$ with $500 \mu \mathrm{g} / \mathrm{ml}$ yeast tRNA and $50 \mu \mathrm{M}$ dithiothreitol (DTT) in diethylpyrocarbonate water and then diluted to an activity of $5 \times 10^{6}$ with hybridization buffer containing $50 \%$ formamide, $0.25 \mathrm{M}$ sodium chloride, $1 \times$ Denhardt's solution, and 10\% dextran sulfate. This hybridization solution was pipetted onto the sections $(80 \mu \mathrm{l} / \mathrm{slide})$, covered with a glass coverslip, and sealed with dextropropoxyphene before incubation for 20 $\mathrm{hr}$ at $58^{\circ} \mathrm{C}$. After hybridization, the slides were washed four times $(5 \mathrm{~min}$ each) in $4 \times \mathrm{SSC}$ before RNase digestion $\left(20 \mu \mathrm{g} / \mathrm{ml}\right.$ for $30 \mathrm{~min}$ at $\left.37^{\circ} \mathrm{C}\right)$ and rinsed at room temperature in decreasing concentrations of SSC that contained $1 \mathrm{~mm}$ DTT $(2 \times, 1 \times, 0.5 \times ; 10 \mathrm{~min}$ each $)$ to a final stringency of $0.1 \times \mathrm{SSC}$ at $65^{\circ} \mathrm{C}$ for $30 \mathrm{~min}$. After dehydration in increasing alcohols, the sections were exposed to DuPont Cronex $x$-ray film (DuPont NEN, Boston, MA) for 4 and $8 \mathrm{~d}$, together with autoradiographic ${ }^{14} \mathrm{C}$ microscales (Amersham, Arlington Heights, IL) before being dipped in NTB-2 liquid emulsion. The dipped autoradiograms were developed $21 \mathrm{~d}$ later with Kodak D-19 developer, and the sections were counterstained with thionin through the emulsion.

Combined immunocytochemistry and in situ hybridization. Methods used in this study are a modification of those described previously (Lorang et al., 1994). Acrolein-fixed tissue sections were used to demonstrate the colocalization of pCREB immunoreactivity with TH, PDYN, and PENK mRNAs. Immunocytochemistry was performed as described above, except that after the treatment with sodium borohydride, the sections were rinsed in $0.02 \mathrm{M} \mathrm{KPBS}$ and preincubated in a blocking buffer solution $(2 \%$ BSA, $5 \mathrm{mM}$ DTT, $0.3 \%$ Triton X-100 in KPBS) overnight at $4^{\circ} \mathrm{C}$. Sections were washed in KPBS and incubated in rabbit anti-rat pCREB (Upstate Biotechnology, lot No. 12994) at a dilution of 1:1500 for $72 \mathrm{hr}$ at $4^{\circ} \mathrm{C}$ and staincd using a Vcetastain Elitc ABC kit (Vector) with diaminobenzidinc as the substrate. The stained sections were mounted onto gelatin- and poly-L-lysine-coated microscope slides. After a $15 \mathrm{~min}$ proteinase $\mathrm{K}$ digestion $\left(5 \mu \mathrm{g} / \mathrm{ml}\right.$ at $\left.37^{\circ} \mathrm{C}\right)$ and acetylation $0.0025 \%$ at room temperature, the sections were dehydrated in ascending alcohols and dried under vacuum for at least $2 \mathrm{hr}$. Procedures of in situ hybridization followed those described above. T7 polymerase was used to transcribe ${ }^{33} \mathrm{P}$-labeled antisense cRNA probe from a 280 bp cDNA insert derived from a PstI/KpnI restriction fragment, which corresponds to nucleotides $1242-$ 1522 of the rat TH gene (Lewis et al., 1987) that was subcloned into the PstI and EcoRI restriction sites of the PGEM-3 transcription vector (Promega, Madison, WI). This plasmid was provided by Dr. E. Lewis (Oregon Health Sciences University). Probes complementary to PDYN mRNA were synthesized using T7 polymerase to transcribe a $733 \mathrm{bp}$ insert that corresponds to a Bam HI-HincII fragment of the main exon of the PDYN gene (Douglass et al., 1989). SP6 polymerase was used to transcribe ${ }^{35}$ S-labeled antisense cRNA probes from a 935 bp Sacl-Smal fragment of plasmid pYSEA1 [generously provided by Dr. S. Sabol (National Institutes of Health)] that are complementary to the entire coding region of rat PENK mRNA (Yoshikawa et al., 1984). After hybridization and posthybridization processing, the sections were exposed to Dupont Cronex $\mathrm{x}$-ray films for $4 \mathrm{~d}$ before being dipped in NBT-2 liquid emulsion. The dipped autoradiograms were developed $14 \mathrm{~d}$ later with Kodak D-19 developer and coverslipped for microscopic observation.

Quantification and analysis. Slides were randomized and numerically coded before analysis. Clearly labeled neurons with darkly stained CREB- and pCREB-immunoreactive nuclei located within the morphological borders of the AVPV (see Fig. 2) were counted at a magnification of $400 \times$ on adjacent series of sections (at a frequency of 1 in 4) through the preoptic region of each animal. The total number of immunoreactive nuclei in the AVPV was estimated by multiplying the total number of stained cells by 4 . Because only nuclei completely contained in the section were counted, a correction factor such as that of Abercrombie (Aber- crombie, 1946) was not used. In the immunohistochemical/in situ hybridization experiments, total numbers of TH, PENK, or PDYN mRNAcontaining neurons in the AVPV were counted, and the presence of a clearly stained, pCREB-immunoreactive. nucleus was determined for each neuron identified as doubly labeled. A cell was considered labeled for each mRNA if the density of silver grains overlying the cell nucleus was greater than three times that of background, and Abercrombie's method was used to correct for double-counting errors (Abercrombie, 1946). The optical density of the autoradiographic images of CREB In RNA on Cronex $x$-ray film was nneasured by using a Macintosh-based image analysis system and National Institutes of Health Image software. Each film was illuminated with a ChromaPro 45 light source, which provided even illumination, and the image was obtained with a Dage M'lI 70 series video camera equipped with a Newvicon tube. The optical density of the autoradiographic images on Cronex $x$-ray film over the AVPV ( $8 \mathrm{~d}$ exposure) at the same level from each brain was measured. A two-way ANOVA was used to test for significant differences among groups in each experiment, and a post hoc Fisher's test was used to identify significant differences between individual groups. A $p$ value of $\leq 0.05$ was defined as significant.

Hormonc assays. Blood samples that were taken immediately before perfusion were collected in Eppendorf tubes, coagulated at room temperature for $2 \mathrm{hr}$, and stored at $4^{\circ} \mathrm{C}$ for $24 \mathrm{hr}$. Serum was separated by centrifugation and stored at $-20^{\circ} \mathrm{C}$ until assayed for estrogen and progesterone by radioimmunoassay (RIA) by the staff of the Oregon Regional Primate Research Center RIA core as described previously (Resko et al., 1975; Hess et al., 1981; Urbanski, 1990). All the samples in each experiment were run in a single assay, with an intra-assay variation of $<8 \%$, and the lower limits of detection were $5 \mathrm{pg} /$ tube in the estrogen assay, $<3.2 \%$ intra-assay variation, and $12 \mathrm{pg} /$ tube lower limits of detection in progesterone assay.

\section{RESULTS}

\section{Regulation of CREB and pCREB by estrogen in the AVPV}

Treatment of ovariectomized female rats with EB caused an increase in serum levels of estradiol (E2) that was slightly above physiological levels within $5 \mathrm{~min}$ after injection, but E2 levels increased rapidly to supraphysiological levels by $30 \mathrm{~min}$, and levels remained in the supraphysiological range for at least

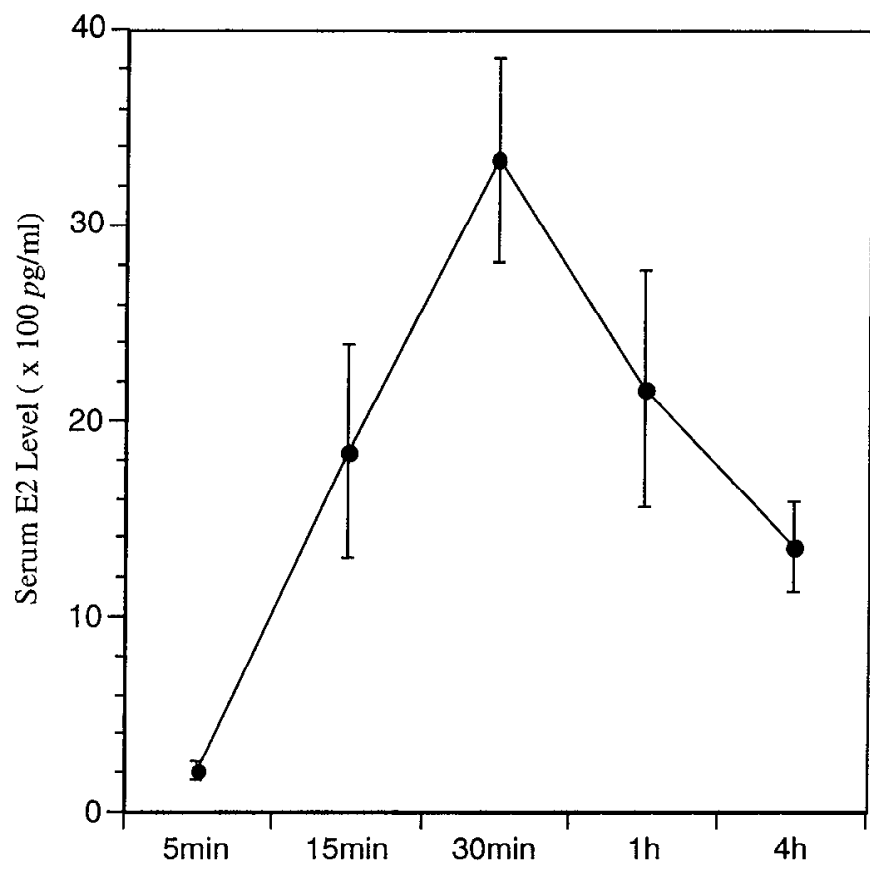

Figure 1. Experiment I: E2 profile. Serum E2 levels $(\times 100 \mathrm{pg} / \mathrm{ml})$ of ovariectomized female rats that received subcutaneous injections of $E B$ and were killed at 5,15 , and $30 \mathrm{~min}$, and 1 or $4 \mathrm{hr}$ after injection. 

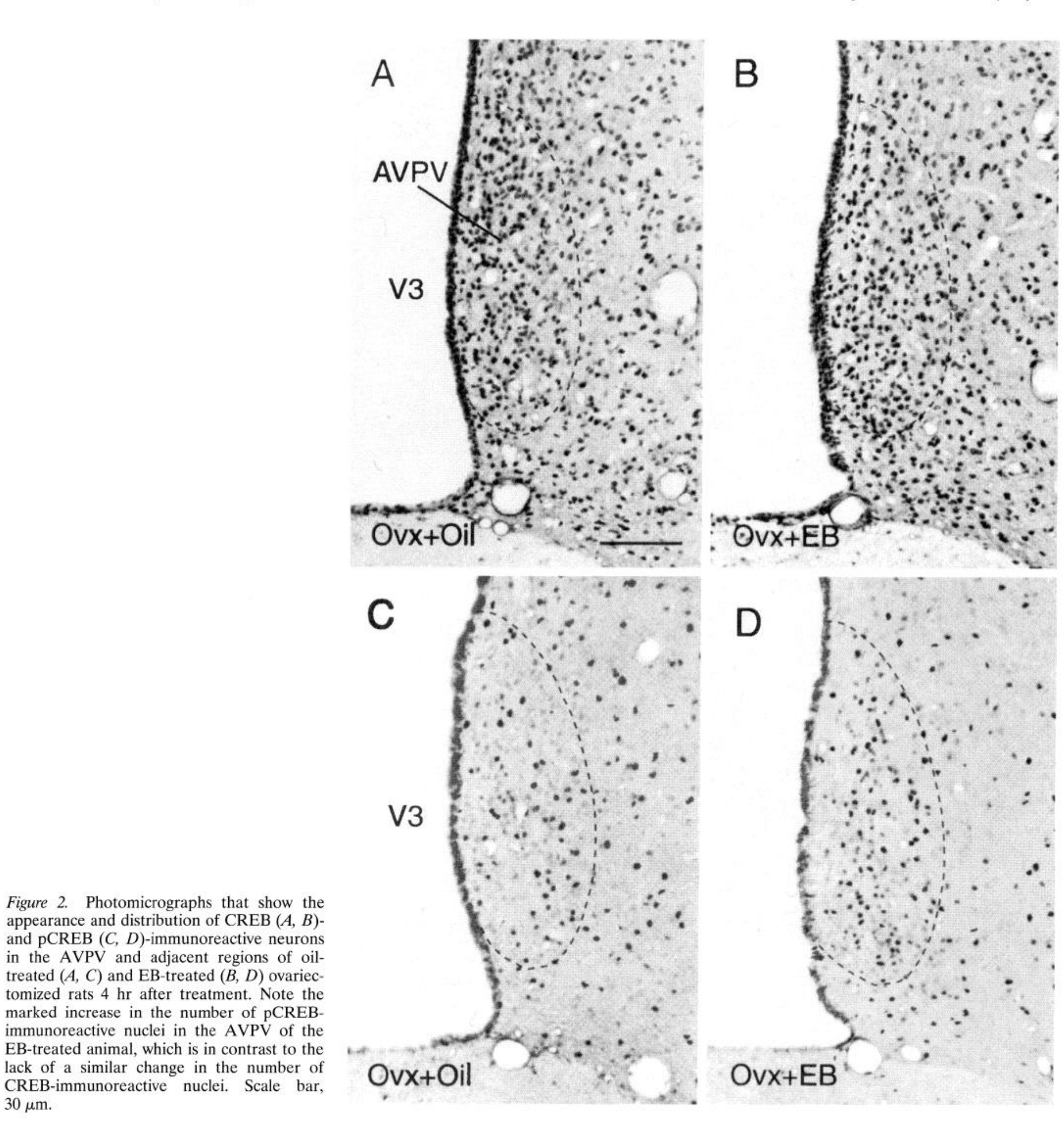

Figure 2. Photomicrographs that show the appearance and distribution of $\operatorname{CREB}(A, B)$ and pCREB $(C, D)$-immunoreactive neurons in the AVPV and adjacent regions of oiltreated $(A, C)$ and EB-treated $(B, D)$ ovariectomized rats $4 \mathrm{hr}$ after treatment. Note the marked increase in the number of pCREBimmunoreactive nuclei in the AVPV of the EB-treated animal, which is in contrast to the lack of a similar change in the number of CREB-immunoreactive nuclei. Scale bar, $30 \mu \mathrm{m}$.

$4 \mathrm{hr}$ (Fig. 1). However, this hormone treatment did not produce a significant change in either the number of CREBimmunoreactive nuclei or the density of CREB mRNAcontaining neurons in the AVPV compared with labeling obtained in animals treated with vehicle alone (Fig. $2 A, B$ ), suggesting that estrogen has no acute effect on expression of CREB in the AVPV. In contrast, the same treatment caused a marked increase in the density of pCREB-immunoreactive nuclei in the AVPV (Fig. $2 C, D$ ). Although there was no significant difference in the numbers of stained cells at either 5 or 15 min after treatment, by $30 \mathrm{~min}$, when serum E2 levels peaked, the AVPV contained $\sim 50 \%$ more pCREB-immunoreactive nuclei in hormone-treated animals compared with the number of stained nuclei in the AVPV of parallel oil-treated controls (Fig. 3, Table 1). This apparent induction in nuclear levels of pCREB was maintained for at least $4 \mathrm{hr}$.

To test the specificity of the estrogenic induction of pCREB immunoreactivity in the AVPV, we evaluated the influence of E2 treatment on pCREB staining in animals that were pretreated with the anti-estrogen Nafoxidine. Intraperitoneal injections of Nafoxidine have been reported to block the action of E2 on sexual behavior and to reduce estradiol binding in the hypothalamus by $\sim 80 \%$ within $6 \mathrm{hr}$ (Wade and Blaustein, 1978). This effect is apparently maintained for up to $4 \mathrm{~d}$. In the present study, pre- 

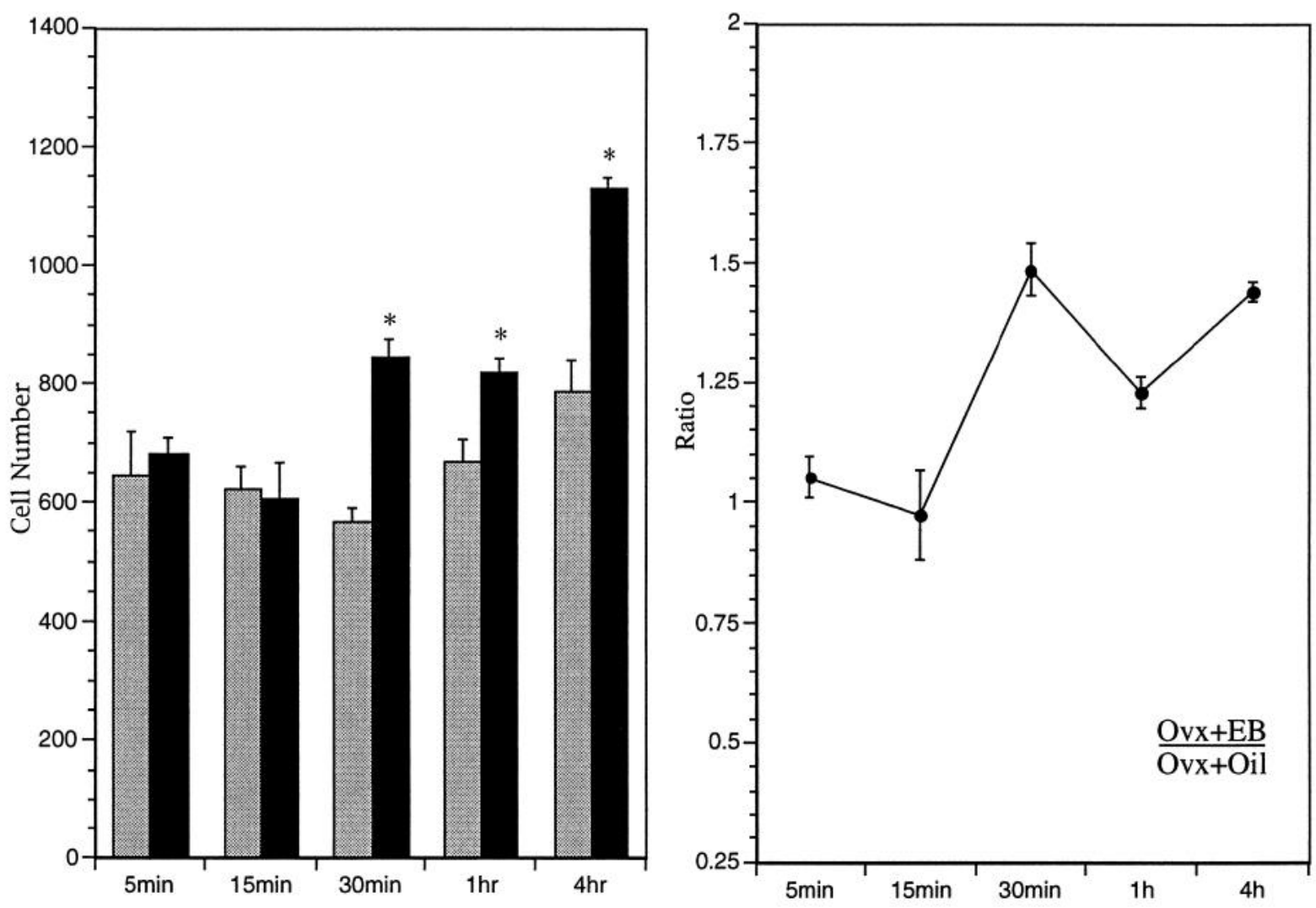

Figure 3. Regulation of pCREB staining in the AVPV by estrogen. Left, Bars indicate mean numbers $( \pm$ SEM) of pCREB-immunoreactive neurons in the AVPV of ovariectomized female rats treated with EB (solid bars) or oil (shaded bars) and killed at 5, 15, and $30 \mathrm{~min}$, and 1 or $4 \mathrm{hr}$ after injection. Asterisks indicate significantly greater mean numbers compared with the ovariectomized female rats treated with oil. Right, Ratio of mean numbers of pCREB-immunoreactive neurons in the AVPV of ovariectomized female rats treated with $\mathrm{EB}(O v x+E B)$ and those in control animals treated with oil $(O v x+O i l)$ at 5,15 , and $30 \mathrm{~min}$, and 1 or $4 \mathrm{hr}$ after injection.

treatment of ovariectomized female rats with Nafoxidine $(4 \mathrm{mg} /$ animal) blocked the ability of EB to increase levels of pCREB immunoreactivity in nuclei of AVPV neurons $4 \mathrm{hr}$ after treatment.

\section{Regulation of CREB and pCREB by progesterone in the AVPV}

The influence of P4 treatment on pCREB staining was evaluated in ovariectomized rats implanted with silastic capsules containing E2. These capsules produced levels of E2 in plasma in the normal physiological range. After receiving subcutaneous injections of P4, serum P4 levels increased within $30 \mathrm{~min}$, were maintained at $50-70 \mathrm{pg} / \mathrm{ml}$ for at least $4 \mathrm{hr}$, and then declined to low levels by 24 hr after treatment (Fig. 4).

In contrast to the effects of EB treatment on pCREBimmunoreactive nuclei in the AVPV, P4 treatment decreased numbers of pCREB-stained nuclei in the AVPV within $30 \mathrm{~min}$.

$\overline{\text { Table 1. Influence of EB treatment on CREB phosphorylation in AVPV }}$

\begin{tabular}{llc} 
Time & Oil-treated & EB-treated \\
\hline $5 \mathrm{~min}$ & $648.0 \pm 69.7$ & $681.3 \pm 27.9$ \\
$15 \mathrm{~min}$ & $624.0 \pm 36.7$ & $608.0 \pm 58.0$ \\
$30 \mathrm{~min}$ & $569.3 \pm 22.4$ & $845.3 \pm 30.8^{a}$ \\
$1 \mathrm{hr}$ & $668.0 \pm 35.9$ & $821.3 \pm 22.4^{b}$ \\
$4 \mathrm{hr}$ & $786.7 \pm 52.1$ & $1132.0 \pm 15.1^{a}$
\end{tabular}

Values represent the mean \pm SEM of the number of labeled cells.

${ }^{a}$ Significantly greater than oil-treated group $(p<0.0001)$.

${ }^{b}$ Significantly greater than oil-treated group $(p<0.01)$.
This significant decrease was followed by a greater than twofold increase in the number of pCREB-immunoreactive nuclei $30 \mathrm{~min}$ later (Fig. 5, Table 2). Levels of pCREB staining in the AVPV declined after $1 \mathrm{hr}$, and no significant differences were apparent between experimental and control animals by $2 \mathrm{hr}$ after progesterone treatment. This biphasic effect of P4 on pCREB staining appeared to be specific, because pretreatment with progesterone receptor antagonist RU486 blocked the suppression and induction of pCREB staining in the AVPV at 30 and $60 \mathrm{~min}$.

The distribution of CREB-immunoreactive nuclei in animals treated with progesterone was similar to that described for EBtreated rats in experiment 1 (see above). No significant differences

Table 2. Influence of $\mathrm{P}_{4}$-treatment on phosphorylation of CREB in AVPV in $E_{2}$-primed rats

\begin{tabular}{lll} 
Time & $\mathrm{E}_{2}+$ oil-treated & $\mathrm{E}_{2}+\mathrm{P}_{4}$-treated \\
\hline $5 \mathrm{~min}$ & $240.0 \pm 24.4$ & $226.7 \pm 29.7$ \\
$15 \mathrm{~min}$ & $184.0 \pm 63.8$ & $193.3 \pm 35.8$ \\
$30 \mathrm{~min}$ & $257.0 \pm 55.2$ & $153.0 \pm 27.0^{a}$ \\
$1 \mathrm{hr}$ & $197.3 \pm 27.6$ & $317.3 \pm 24.3^{b}$ \\
$2 \mathrm{hr}$ & $189.3 \pm 10.7$ & $238.7 \pm 36.8$ \\
$4 \mathrm{hr}$ & $258.0 \pm 54.3$ & $284.0 \pm 34.6$ \\
$24 \mathrm{hr}$ & $194.0 \pm 32.7$ & $205.0 \pm 24.2$
\end{tabular}

Values represent the mean \pm SEM of the number of labeled cells.

${ }^{a}$ Significantly greater than $\mathrm{E}_{2}+$ oil-treated group $(p<0.05)$.

${ }^{b}$ Significantly greater than $\mathrm{E}_{2}+$ oil-treated group $(p<0.05)$. 


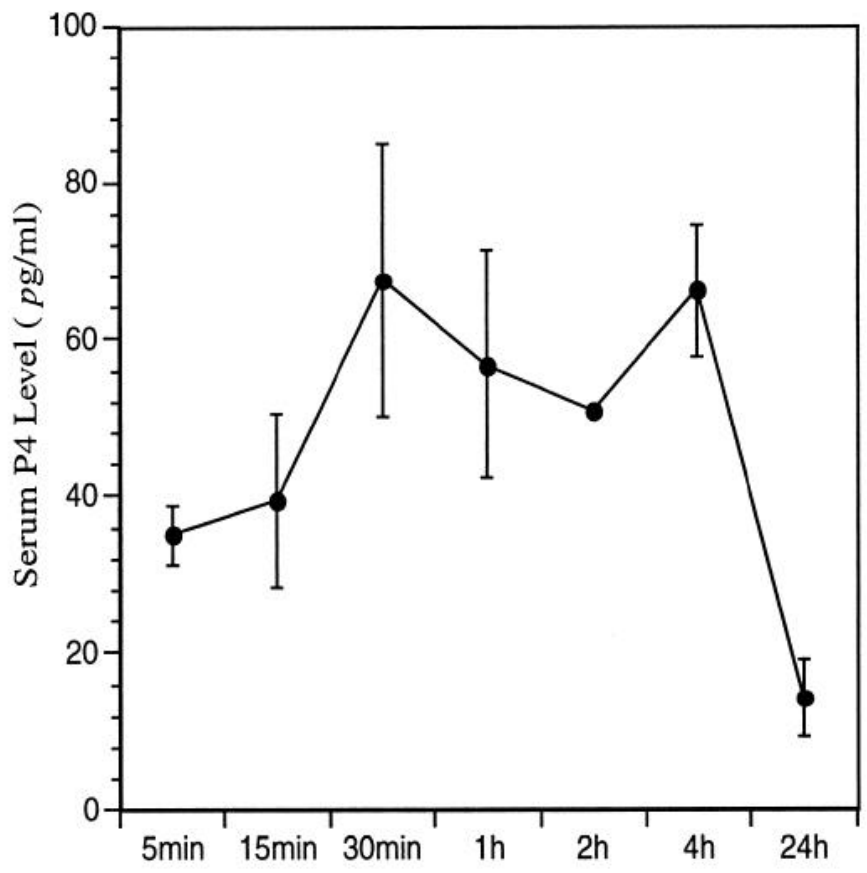

Figure 4. Experiment II: P4 profile. P4 (solid line) levels $(\mathrm{pg} / \mathrm{ml})$ in estrogen-primed rats (E2 levels, $38-78 \mathrm{pg} / \mathrm{ml}$ ) treated with progesterone and killed at 5, 15, and $30 \mathrm{~min}$, and 1, 2, 4, and $24 \mathrm{hr}$ after injection.

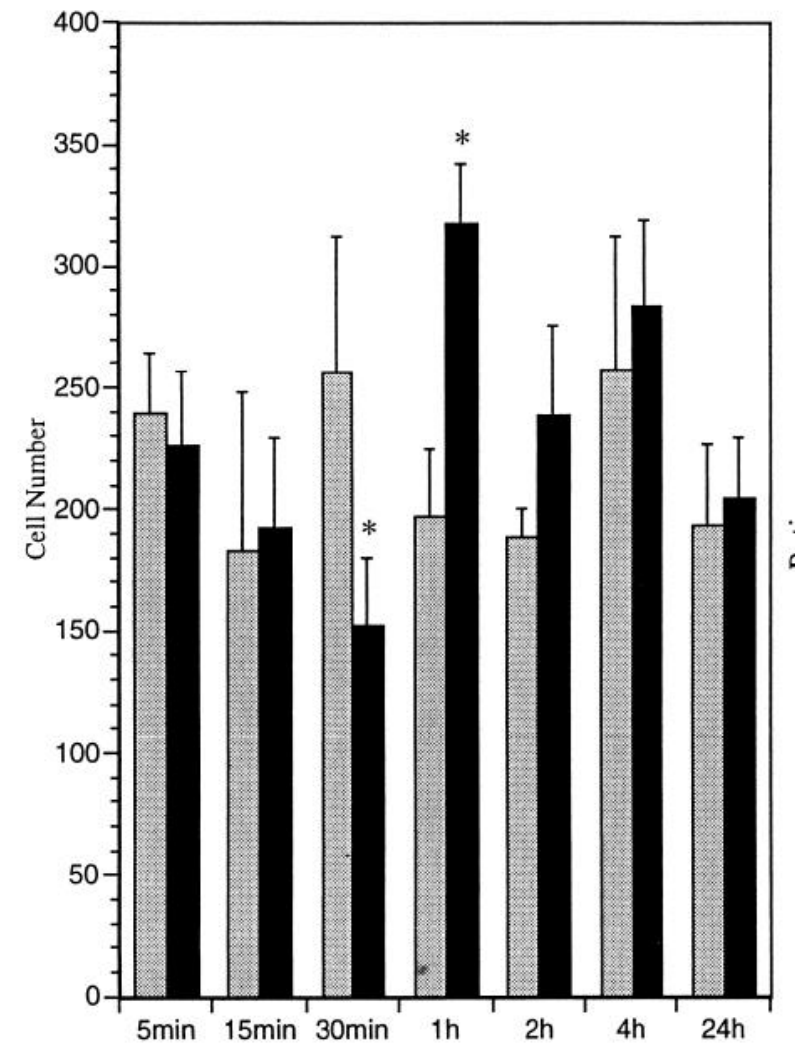

in the numbers of stained neurons in the AVPV were observed between the P4-treated and control groups. This observation was verified by the results of in situ hybridization experiments, which showed no apparent change in levels of CREB mRNA in the AVPV of P4-treated animals relative to those of control animals.

\section{Colocalization of pCREB with TH, PDYN, and PENK mRNAs}

To determine whether hormone treatments induce expression of pCREB specifically in TH, PDYN, or PENK mRNA-containing neurons, we performed a series of combined immunohistochemi$\mathrm{cal} /$ in situ hybridization experiments. Two separate groups of experimental animals with either $1 \mathrm{hr}$ EB treatment or $1 \mathrm{hr}$ E2 + P4 treatment were used in these experiments. Although processing sections for immunocytochemistry before in situ hybridization reduced the density of silver grains over labeled cells relative to sections processed for in situ hybridization alone, immunostaining did not alter the overall distribution of PDYN, PENK, and TH mRNAcontaining neurons in the AVPV identified in doubly stained material. Approximately 26 and $28 \%$ of the PDYN mRNA-containing cells had clearly stained pCREB-immunoreactive nuclei in EB- and E2 + P4-treated animals, respectively (Fig. 6A, Table 3). However, the percentage of PENK mRNA-containing neurons in the AVPV that were doubly labeled for pCREB appeared to be somewhat higher; $39 \%$ of PENK-labeled cells were doubly labeled in EBtreated animals, and $56 \%$ were doubly labeled in E2 + P4-treated rats (Fig. 6B, Table 3). Approximately $33 \%$ of TH mRNA-containing neurons in the AVPV had clearly stained pCREB-immunoreactive nuclei in either EB- or E2 + P4-treated rats (Table 3).

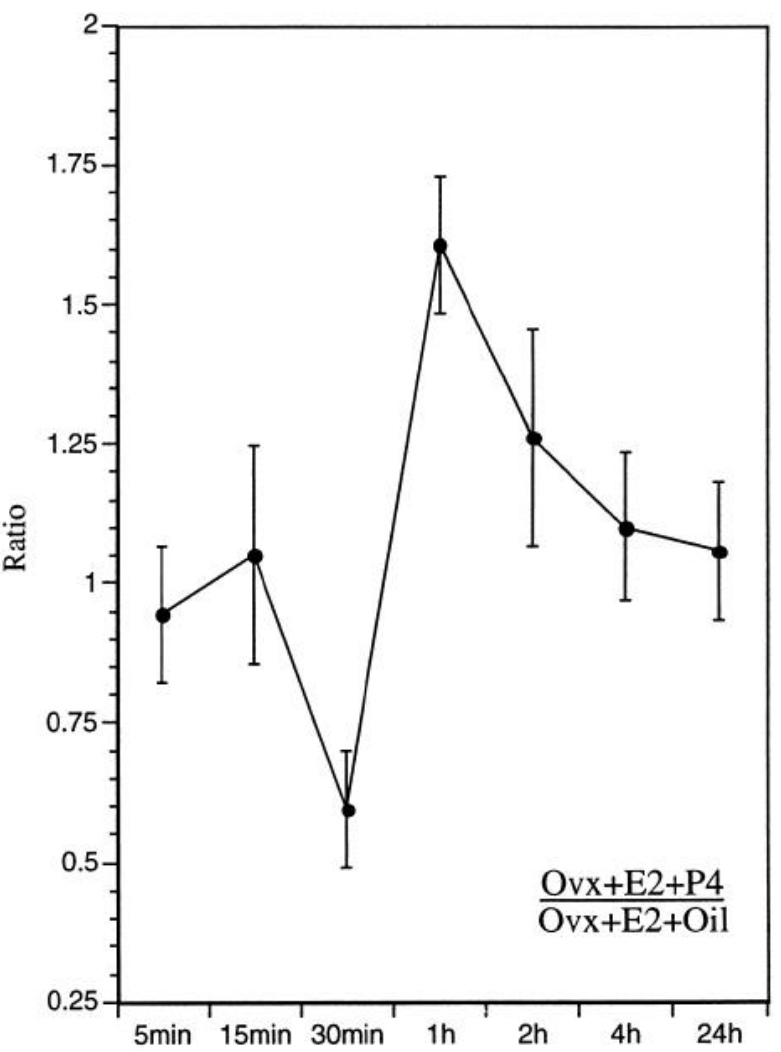

Figure 5. Regulation of pCREB staining in the AVPV by progesterone. Left, Bars indicate mean numbers ( \pm SEM) of pCREB-immunoreactive neurons in the AVPV of estrogen-primed female rats treated with progesterone (solid bars) or oil (shaded bars) and killed at 5, 15, 30 min, and 1, 2, 4, or 24 hr after injection. Asterisks indicate significantly greater mean numbers compared with estrogen-primed female rats treated with oil. Right, Ratio of mean numbers of pCREB-immunoreactive neurons in the AVPV of estrogen-primed female rats treated with progesterone $(O v x+E 2+P 4)$ and those in parallel groups of rats treated with oil $(O v x+E 2+O i l)$ at 5,15 , and $30 \mathrm{~min}$, and 1,2, 4, or $24 \mathrm{hr}$ after injection. 

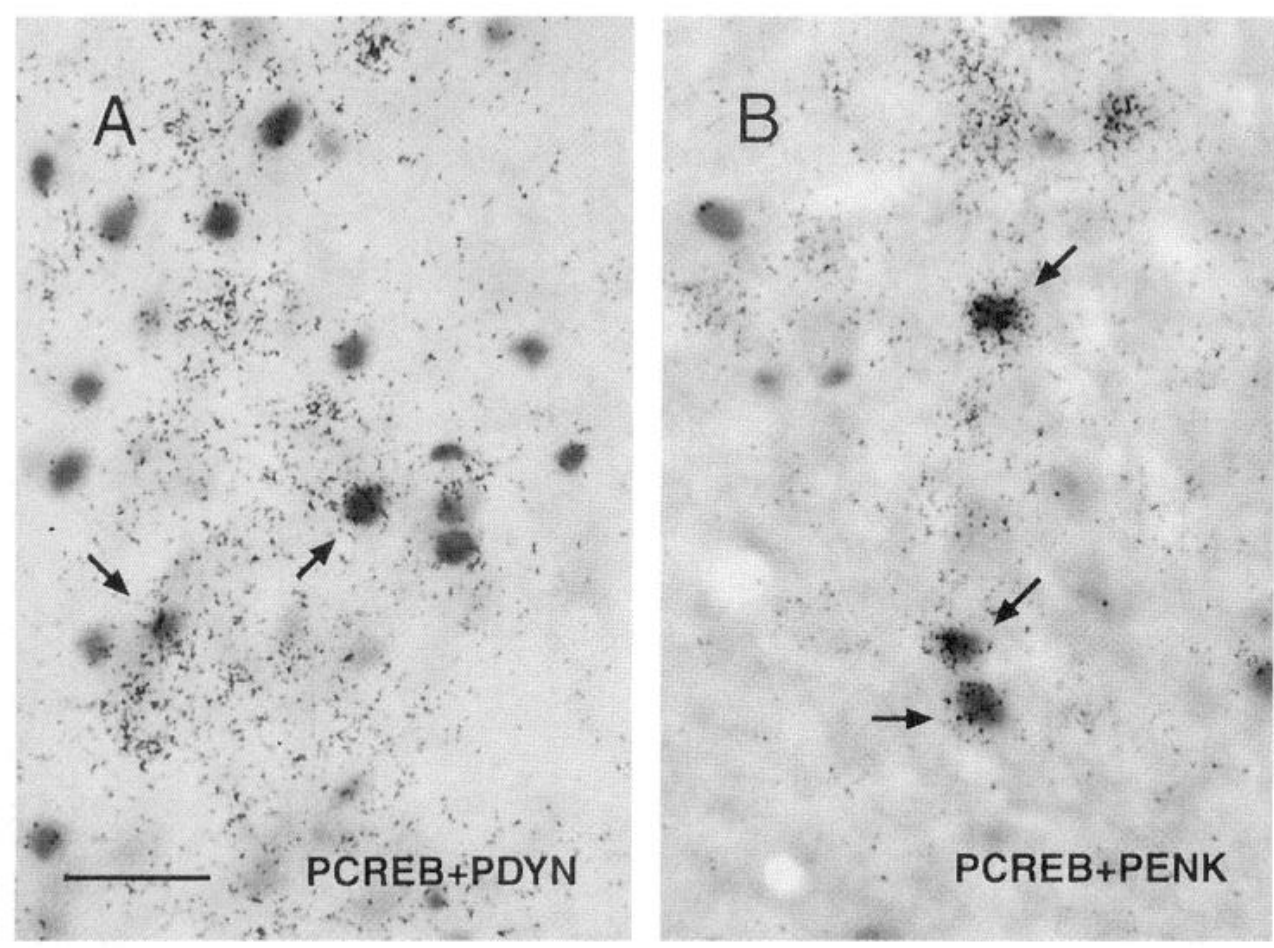

Figure 6. Bright-field micrographs of PDYN mRNA (black grains)-containing neurons $(A)$ and PENK mRNA (black grains)-containing neurons $(B)$ in the AVPV doubly labeled for pCREB (stained nuclei) by using combined immunocytochemistry and in situ hybridization (arrows). Scale bar, $10 \mu \mathrm{m}$.

\section{DISCUSSION}

The results of this study indicate that the activity of the transcription factor CREB is regulated in AVPV neurons by both E2 and P4. Acute treatment of ovariectomized rats with subcutaneous injections of E2 produced high levels of plasma E2 within $30 \mathrm{~min}$ after injection and was accompanied by a significant increase in nuclear staining for pCREB. The exact temporal relationship between the observed increases in PCREB and E2 stimulation of AVPV neurons remains unresolved because there is an unknown delay between the time of injection and when the local concentration of E2 in the AVPV increases. However, plasma levels of E2 increased rapidly in our animals between 15 and $30 \mathrm{~min}$ after treatment. Thus, it appears that AVPV neurons are exposed to increased levels of E2 between 15 and $30 \mathrm{~min}$ after treatment, the period immediately preceding the observed increase in pCREB staining. Although it may appear to be surprising that levels of pCREB staining did not return to baseline $4 \mathrm{hr}$ after treatment, this may be because plasma levels of E2 remained high throughout the time points studied. Treatment of E2-primed rats with P4 resulted in elevated plasma levels of $\mathrm{P} 4$ that reached proestrus levels by $30 \mathrm{~min}$ after injection and returned to baseline within 24 $\mathrm{hr}$. The increase in plasma P4 levels correlated with an equally rapid, but bimodal response in pCREB staining in the AVPV. Within $30 \mathrm{~min}$ of $\mathrm{P} 4$ treatment, pCREB first decreased then doubled after an additional $30 \mathrm{~min}$ before returning to baseline 15 min later. These hormonally regulated changes in nuclear levels of pCREB staining were not accompanied by similar changes in CREB immunostaining or mRNA levels, indicating that the reg- ulation of pCREB immunoreactivity observed in the AVPV is attributable to hormonal regulation of CREB phosphorylation as opposed to regulation of CREB gene expression, or changes in nuclear levels of CREB protein. Moreover, the rapid effects of the hormone treatments on PCREB staining are also not consistent with the synthesis of new protein, however, this possibility has not been examined experimentally. Although the antisera we used can differentiate between phosphorylated and nonphosphorylated forms of CREB, pCREB antibody also appears to recognize ATF-like proteins (Ginty et al., 1993), so our results may reflect hormonal regulation of phosphorylation of these proteins as well.

In general, our results are consistent with other studies that evaluated physiological regulation of CREB phosphorylation in response to photic stimuli, salt loading, or stress, which suggests that CREB phosphorylation may mediate neuronal responses to a variety of physiological stimuli. A rapid increase in pCREB staining was observed in the suprachiasmatic nucleus in light/dark entrained hamsters exposed to light during their subjective night (Ginty et al., 1993). Similarly, treatment of transgenic mice with hypertonic saline induced pCREB staining in neurons that express a proenkephalin- $\beta$-galactosidase fusion gene within $10 \mathrm{~min}$ of injection (Borsook et al., 1994). Although we did not observe a significant change in pCREB staining in the AVPV until 30 min after injection, the increase in pCREB-immunoreactive nuclei correlates with the first marked increase in plasma levels of E2. The bimodal response of CREB phosphorylation to P4 also appears to be quite rapid, because plasma levels of P4 were not elevated significantly until $30 \mathrm{~min}$ after injection. Estrogen (Insel,

Table 3. Colocalization of pCREB immunoreactivity with PDYN, PENK, and TH mRNAs in AVPV

\begin{tabular}{|c|c|c|c|c|c|c|c|c|c|}
\hline Treatment & PDYN & PDYN + pCREB & $\%^{a}$ & PENK & PENK + pCREB & $\%$ & $\mathrm{TH}$ & $\mathrm{TH}+\mathrm{pCREB}$ & $\%$ \\
\hline EB & $120.3 \pm 22.0$ & $30.7 \pm 8.3$ & 25.5 & $72.6 \pm 28.8$ & $28.0 \pm 14.4$ & 38.6 & $73.3 \pm 10.2$ & $24.0 \pm 14.4$ & 32.7 \\
\hline$E+P$ & $140.8 \pm 18.8$ & $40.0 \pm 10.6$ & 28.4 & $80.7 \pm 9.2$ & $45.3 \pm 12.2$ & 56.2 & $70.4 \pm 5.8$ & $24.0 \pm 6.9$ & 34.1 \\
\hline
\end{tabular}

Values represent the mean \pm SEM of the number of labeled cells.

${ }^{a}$ Percentage numbers indicate the percentage of PDYN, PENK, or TH mRNA-containing neurons that were doubly labeled. 
1990) and progesterone (Watson et al., 1993) have been reported to induce levels of Fos immunoreactivity in AVPV neurons, but these responses appear to be delayed somewhat relative to CREB phosphorylation, which is consistent with the suggestion that activation of CREB may contribute to increased c-fos gene expression (Sheng et al., 1990).

The hormonal regulation of pCREB immunoreactivity in the AVPV appears to be receptor-mediated, because pretreatment with the anti-estrogen Nafoxidine blocked the effects of E2 on pCREB immunostaining, and pretreatment of E2-primed rats with the antiprogestin RU486 blocked the biphasic effect of P4 on pCREB. Nafoxidine has been shown previously to reduce E2 receptor binding and prevent receptor-mediated actions of E2 on reproductive behavior (Wade and Blaustein, 1978). Similarly, RU486 is a potent P4 antagonist that binds irreversibly to the PR and can block physiological effects of circulating P4 on gonadotropin secretion (Smith et al., 1989). However, the molecular mechanism for the action of the ER and PR on CREB phosphorylation is unknown, and ovarian steroids have been reported to alter neuronal activity in regions that do not express their cognate receptors (Smith et al., 1987, 1989).

Although transcriptional regulation by steroid hormone receptors has traditionally been viewed as a separate regulatory pathway from that involving stimulus transcription coupling mediated by second messengers, recent evidence suggests that there is a substantial amount of crosstalk between these two classes of signal transduction pathways. For example, Power and colleagues demonstrated that dopamine antagonists can alter the ability of the PR to activate gene expression, perhaps by influencing phosphorylation of the receptor (Power et al., 1991), and dopaminestimulated increases in hypothalamic c $\Lambda$ MP levels are enhanced during proestrus in normally cycling rats (Barr et al., 1983). Changes in cAMP levels, or activation of PKA and PKC, may influence the action of steroid hormone receptors in mammary carcinoma cells (Denner et al., 1990; Beck et al., 1992; Cho and Katzenellenbogen, 1993), and steroid hormones have been shown to regulate $\mathrm{CAMP}$-mediated gene expression through modulation of the cAMP system (Aronica el al., 1994). Less information is available regarding acute effects of steroid hormones on neuronal signal transduction, but estrogen and/or progesterone have been shown to alter production of cAMP and $\mathrm{IP}_{3}$ (Kow and Mobbs, 1994), as well as to influence neuronal signaling in response to neurotransmitters (Kow and Pfaff, 1985; Petitti and Etgen, 1989, 1990; Lagrange et al., 1994).

P4 appears to have biphasic effects on the secretion of luteinizing hormone in estrogen-primed rats with short-term treatments causing increased secretion of luteinizing hormonc, but P4 exerts negative feedback effects 24 hr later (Barraclough et al., 1986). It is interesting to speculate that the biphasic effects of P4 on CREB phosphorylation observed in the AVPV may participate in mediating the biphasic effects of $\mathrm{P} 4$ on $\mathrm{GnRH}$ secretion, although at present there is no convincing evidence to support this suggestion. Whether the changes in levels of pCREB in AVPV neurons specifically influence expression of TH and PDYN is unknown, but the inhibition of TH and the stimulation of PDYN expression by E2 may be mediated by hormonal regulation of CREB phosphorylation. Our double-labeling experiments indicate that E2 and P4 regulate the phosphorylation of CREB in at least a subpopulation of these neurons, but clarification of this issue will require a detailed analysis of TH and PDYN gene expression in the AVPV by using intronic probes to more directly correlate changes in CREB phosphorylation with changes in transcription. The hormonal induction of pCREB in PENK mRNAcontaining neurons was surprising given that neither $\mathrm{E} 2$ nor $\mathrm{P} 4$ treatment causes significant changes in PENK gene expression (Simerly, 1991, 1992). However, a small but significant decrease in PENK mRNA was detected in intact female rats during proestrus (R. Simerly et al., unpublished data), which may reflect the combined effects of both endocrine and neural factors yet to be identified.

Whether E2 and P4 regulate CREB phosphorylation in AVPV neurons by acting directly through their cognate hormone receptors expressed in the same cells, or act via the activation of hormone-sensitive neurons that provide inputs to AVPV neurons is not resolved. Most of the neurons in the AVPV express receptors for ovarian steroid hormones (Simerly et al., in press), and systemic injections of E2 alter the electrophysiological activity of neurons in the region of the AVPV (Kubo et al., 1975). However, the AVPV receives strong inputs from other forebrain regions containing neurons that express high levels of estrogen and progesterone receptors, such as the medial preoptic nucleus and arcuate nucleus of the hypothalamus (Simerly and Swanson, 1988; Simerly et al., 1990; Simerly, 1993, 1995a). Thus, E2 and P4 may regulate phosphorylation of CREB in AVPV neurons transsynaptically by stimulating the activity of neurons in such regions (Armstrong and Montminy, 1993). A preliminary report of increased staining for pCREB in the medial preoptic nucleus in response to $\mathrm{E} 2$ treatment is consistent with this possibility (Zhou and Dorsa, 1994).

Although these results suggest that CREB phosphorylation in the AVPV may mediate the effects of steroid hormones on $\mathrm{TH}$, PDYN, and possibly PENK gene expression, the physiological importance of these molecular events is unknown. The results of recent anterograde transport studies indicate that neurons in the AVPV project directly to a subpopulation of GnRH-containing neurons in the rostral part of the preoptic region ( $\mathrm{Gu}$ and Simerly, 1994), although the identity of neurotransmitters expressed in this projection has not been demonstrated. This latter observation is parlicularly interesting because the distribution of $\mathrm{GnRH}$ cells that receive AVPV inputs overlaps with that of GnRH neurons that show hormonally induced changes in Fos immunoreactivity (Lee et al., 1990a,b), suggesting that changes in c-fos expression in GnRH neurons may be attributable to transsynaptic activation by hormonally stimulated AVPV neurons. The impact of CREB activation in AVPV dynorphin-containing neurons on gonadotropin secretion is equally unclear. Abundant pharmacological evidence supports an inhibitory role for opioid peptides on luteinizing hormone secretion and suggests that this inhibition is regulated by circulating ovarian steroid hormones (Kalra, 1993). Dynorphin-containing neurons in the AVPV are sexually dimorphic, and PDYN mRNA is reduced on the afternoon of proestrus (Simerly, 1991, 1992), suggesting that the impact of dynorphincontaining projections from the AVPV on postsynaptic targets will be reduced on the afternoon of proestrus during the preovulatory surge. We therefore propose that the induction of CREB phosphorylation in dopaminergic and dynorphin-containing neurons of the AVPV may represent an important molecular component of hormonal feedback on neural systems that regulate gonadotropin secretion.

\section{REFERENCES}

Abercrombie M (1946) Estimation of nuclear population from microtomic sections. Anat Rec 94:239-247. 
Armstrong RC, Montminy MR (1993) Transsynaptic control of gene expression. Annu Rev Neurosci 16:17-29.

Aronica SM, Kraus WL, Katzenellenbogen BS (1994) Estrogen action via the CAMP signaling pathway: stimulation of adenylate cyclase and cAMP-regulated gene transcription. Proc Natl Acad Sci USA 91:8517-8521.

Barr GA, Ahn HS, Makman MH (1983) Dopamine-stimulated adenylate cyclase in hypothalamus: influence of estrous cycle in female and castration in male rats. Brain Res 277:299-303.

Barraclough CA, Camp P, Weiland N, Akabori A (1986) Stimulatory versus inhibitory effects of progesterone on estrogen-induced phasic $\mathbf{L H}$ and prolactin secretion correlated with estrogen nuclear and progestin cytosol receptor concentrations in brain and pituitary gland. Neuroendocrinology 42:6-14.

Beck CA, Weigel WL, Edwards DP (1992) Hormone and cellular modulators of protein phosphorylation of transcriptional activity, DNA binding and phosphorylation of human progesterone receptor. Mol Endocrinol 6:607-620.

Borsook D, Konradi C, Falkowski O, Comb M, Hyman SE (1994) Molecular mechanisms of stress-induced proenkephalin gene regulation: CREB interacts with the proenkephalin gene in the mouse hypothalamus and is phosphorylated in response to hyperosmolar stress. Mol Endocrinol 8:240-248.

Canteras NS, Simerly RB, Swanson LW (1992a) Projections of the ventral premamillary nucleus. J Comp Neurol 324:195-212.

Canteras NS, Simerly RB, Swanson LW (1992b) Connections of the posterior nucleus of the amygdala. J Comp Neurol 324:143-179.

Canteras NS, Simerly RB, Swanson LW (1995) Organization of projections from the medial nucleus of the amygdala: a PHAL study in the rat. J Comp Neurol 360:213-245.

Cho H, Katzenellenbogen BS (1993) Synergistic activation of estrogen receptor-mediated transcription by estradiol and protein kinase activators. Mol Endocrinol 7:441-452.

Chrivia JC, Kwok RPS, Lamb N, Hagiwara M, Montminy MR, Goodman RH (1993) Phosphorylated CREB binds specifically to the nuclear protein CBP. Nature 365:855-859.

Cole RL, Konradi C, Douglass J, Hyman SE (1995) Neuronal adaptation to amphetamine and dopamine: molecular mechanisms of prodynorphin gene regulation in rat striatum. Neuron 14:813-823.

Delmas V, Molina CA, Lalli E, de Groot R, Foulkes NS, Masquilier D, Sassone-Corsi P (1994) Complexity and versatility of the transcriptional response to cAMP. Rev Physiol Biochem Pharmacol 124:1-28.

Denner LA, Weigel NL, Maxwell BL, Schrader WT (1990) Regulation of progesterone receptor-mediated transcription by phosphorylation. Science 250:1740-1743.

Douglass J, McMurray CT, Garrett JE, Adelman JP, Calavetta L (1989) Characterization of the rat prodynorphin gene. Mol Endocrinol 3:2070-2078

Douglass J, McKinzie AA, Pollock KM (1994) Identification of multiple DNA elements regulating basal and protein kinase A-induced transcriptional expression of the rat prodynorphin gene. Mol Endocrinol $8: 333-344$

Ginty DD, Bading H, Greenberg ME (1992) Trans-synaptic regulation of gene expression. Curr Opin Neurobiol 2:312-316.

Ginty DD, Kornhauser JM, Thompson MA, Bading H, Mayo KE, Takahashi JS, Greenberg ME (1993) Regulation of CREB phosphorylation in the suprachiasmatic nucleus by light and a circadian clock. Science 260:238-241.

Gonzalez GA, Montminy MR (1989) Cyclic AMP stimulates somatostatin gene transcription by phosphorylation of CREB at serine 133. Cell 59:675-680.

Goodman RH (1990) Regulation of neuropeptide gene expression. Annu Rev Neurosci 13:111-127.

Gu GB, Simerly RB (1994) Efferent connections of the anteroventral periventricular nucleus of the hypothalamus in the female rat. Soc Neurosci Abstr 20:1739.

Harrison NL, Majewska MD, Meyers DER, Barker JL (1989) Rapid actions of steroids on CNS neurons. In: Neural control on reproductive function (Lakoski JM, Perez-Polo JR, Rassin DK, eds), pp 137-166. New York: Wiley.

Hess DL, Spies HG, Hendrickx AG (1981) Diurnal steroid patterns during gestation in the Rhesus macaque: onset, daily variation, and the effects of dexamethasone treatment. Biol Reprod 24:609-616.
Hoffman GE, Smith MS, Fitzsimmons MD (1992) Detecting steroidal effects on immediate early gene expression in the hypothalamus. Neuroprotocols 1:52-66.

Insel TR (1990) Regional induction of c-fos-like protein in rat brain after estradiol administration. Endocrinology 126:1849-1853.

Kalra SP (1993) Mandatory neuropeptide-steroid signaling for the preovulatory luteinizing hormone-releasing hormone discharge. Endocr Rev 14:507-538.

Kelly MJ (1982) Electrical effects of steroids in neurons. In: Hormonally active brain peptides (McKerns KW, Pantic V, eds), pp 253-277. New York: Plenum.

Kow LM, Mobbs CV (1994) Roles of second-messenger systems and neuronal activity in the regulation of lordosis by neurotransmitters, neuropeptides, and estrogen: a review. Neurosci Biohav Rev 18:251-268.

Kow LM, Pfaff DW (1985) Estrogen effects on neuronal responsiveness to electrical and neurotransmitter stimulation: an in vitro study on the ventromedial nucleus of the hypothalamus. Brain Res 347:1-10.

Kow LM, Mobbs CV, Pfaff DW (1994) Roles of second-messenger systems and neuronal activity in the regulation of lordosis by neurotransmitters, neuropeptides, and estrogen: a review. Neurosci Biobehav Rev 18:251-268.

Kubo K, Gorski RA, Kawakami M (1975) Effects of estrogen on neuronal excitability in the hippocampal-septal-hypothalamic system. Neuroendocrinology 18:176-191.

Kwok RPS, Lundblad JR, Chrivia JC, Richards JP, Bächinger HP, Brennan RG, Roberts SGE, Green MR, Goodman RH (1994) Nuclear protein CBP is a coactivator for the transcription factor CREB. Nature 370:223-226.

Lagrange AH, Ronnekleiv OK, Kelly MJ (1994) The potency of $\mu$-opioid hyperpolarization of hypothalamic arcuate neurons is rapidly attenuated by $17 \beta$-estradiol. J Neurosci 14:6196-6204.

Lazaroff M, Patankar S, Yoon SO, Chikaraishi DM (1995) The cyclic AMP response element directs tyrosine hydroxylase expression in catecholaminergic central and peripheral nervous system cell lines from transgenic mice. J Biol Chem 270:21579-21589.

Lee W-S, Smith MS, Iloffman GE (1990a) Progesterone enhances the surge of luteinizing hormone by increasing the activation of luteinizing hormone-releasing hormone neurons. Endocrinology 127:2604-2609.

Lee W-S, Smith MS, Hoffman GE (1990b) Luteinizing hormonereleasing hormone neurons express Fos protein during the proestrous surge of luteinizing hormone. Proc Natl Acad Sci USA 87:5163-5167.

Lewis EJ, Harrington CA, Chikaraishi DM (1987) Transcriptional regulation of the tyrosine hydroxylase gene by glucocorticoid and cyclic AMP. Proc Natl Acad Sci USA 84:3550-3554.

Lorang D, Amara SG, Simerly RB (1994) Cell-type specific expression of catecholamine transporters in the rat brain. J Neurosci 14:4903-4914.

Meyer TE, Habener JF (1993) Cyclic adenosine 3',5'-monophosphate response element binding protein (CREB) and related transcriptionactivating deoxyribonucleic acid-binding proteins. Endocr Rev $14: 269-290$.

Petitti N, Etgen AM (1989) Progesterone depression of norepinephrinestimulated cAMP accumulation in hypothalamic slices. Mol Brain Res 5:109-119.

Petitti N, Etgen AM (1990) $\beta_{1}$-Adrenoreceptor augmentation of $\beta$-stimulated cAMP formation is enhanced by estrogen and reduced by progesterone in rat hypothalamic slices. J Neurosci 10:2842-2849.

Power RF, Mani SK, Codina J, Conneely OM, O'Malley BW (1991) Dopaminergic and ligand-independent activation of steroid hormone receptors. Science 254:1636-1639.

Resko JA, Ploem JG, Stadelman HC (1975) Estrogens in fetal and maternal plasma of Rhesus monkeys. Endocrinology 97:425-430.

Schumacher M (1990) Rapid membrane effects of steroid hormones: an emerging concept in neuroendocrinology. Trends Neurosci 13:359-362.

Sheng M, McFadden G, Greenberg ME (1990) Membrane depolarization and calcium induce c-fos transcription via phosphorylation of transcription factor CREB. Neuron 4:571-582.

Simerly RB (1989) Hormonal control of the development and regulation of tyrosine hydroxylase expression within a sexually dimorphic population of dopaminergic cells in the hypothalamus. Mol Brain Res 6:297-310.

Simerly RB (1991) Prodynorphin and proenkephalin gene expression in the anteroventral periventricular nucleus of the rat: sexual differentiation and hormonal regulation. Mol Cell Neurosci 2:473-484. 
Simerly RB (1992) Hormonal regulation of tyrosine hydroxylase and opioid peptide gene expression in the hypothalamus. Soc Neurosei Abstr 18:1085.

Simerly RB (1993) Distribution and regulation of steroid hormone receptor gene expression in the central nervous system. In: Advances in neurology, Vol 59 (Seil FJ, ed), pp 207-226. New York: Raven.

Simerly RB (1995a) Anatomical substrates of hypothalamic integration. In: The rat nervous system (Paxinos G, ed), pp 353-376. San Francisco: Academic.

Simerly RB (1995b) Hormonal regulation of limbic and hypothalamic pathways. In: Neurobiological effects of sex steroid hormones (Micevych PE, Hammer JR, eds), pp 85-114. Cambridge, UK: Cambridge UP.

Simerly RB, Swanson LW (1988) Projections of the medial preoptic nucleus: a Phaseolus vulgaris leucoagglutinin anterograde tract-tracing study in the rat. J Comp Neurol 270:209-242.

Simerly RB, McCall LD, Watson SJ (1988) The distribution of opioid peptides in the preoptic region: immunohistochemical evidence for a steroid sensitive enkephalin sexual dimorphism. J Comp Neurol 276:442-459.

Simerly RB, Young BJ, Capozza MA, Swanson LW (1989) Estrogen differentially regulates neuropeptide gene expression in a sexually dimorphic olfactory pathway. Proc Natl Acad Sci USA 86:4766-4770.

Simerly RB, Chang C, Muramatsu M, Swanson LW (1990) Distribution of androgen and estrogen receptor mRNA-containing cells in the rat brain: an in situ hybridization study. J Comp Neurol 294:76-95.

Simerly RB, Carr AM, Zee MC, Lorang D (1996) Ovarian steroid regulation of estrogen and progesterone receptor messenger ribonucleic acid in the anteroventral periventricular nucleus of the rat. J Neuroendocrinol 8:45-56.

Simmons DM, Arriza JL, Swanson SW (1989) A complete protocol for in situ hybridization of messenger RNAs in brain and other tissues with radio-labeled single-stranded RNA probes. J Histotechnol 12:169-181.
Smith MS, Fox SR, Chatterton RT (1989) Role of proestrous progesterone secretion in suppressing basal pulsatile LII secretion during estrus of the estrous cycle. Neuroendocrinology 50:308-314.

Smith SS, Waterhouse BD, Woodward DJ (1987) Locally applied progesterone metabolites alter neuronal responsiveness in the cerebellum. Brain Res Bull 18:739-747.

Smith SS, Woodward DJ, Chapin JK (1989) Sex steroids modulate motorcorrelated increases in cerebellar discharge. Brain Res 476:307-316.

Swanson LW (1987) The hypothalamus. In: Handbook of chemical neuroanatomy. Vol 5, Integrated systems of the CNS, Part I (Björklund A, Hökfelt T, Swanson LW, eds), pp 1-124. Amsterdam: Elsevier.

Urbanski HF (1990) A role for $N$-methyl-D-aspartate receptors in the control of seasonal breeding. Endocrinology 127:2223-2228.

Wade GN, Blaustein JD (1978) Effects of an anti-estrogen on neural estradiol binding and on behaviors in female rats. Endocrinology 102:245-251.

Watson JR, Seksaria SL, Carlson SL, Langub JR (1993) Immunoreactivity of c-FOS in the anteroventral periventricular nucleus during steroid-induced gonadotropin secretion. Soc Neurosci Abstr 19:312.

Wise PM, Camp-Grossman P, Barraclough CA (1981) Effects of estradiol and progesterone on plasma gonadotropins, prolactin, and LHRH in specific brain areas of ovariectomized rats. Biol Reprod 24:820-830.

Wong M, Moss RL (1992) Long-term and short-term electrophysiological effects of estrogen on the synaptic properties of hippocampal CA1 neurons. J Neurosci 12:3217-3225.

Yoshikawa K, Williams C, Sabol SL (1984) Rat brain preproenkephalin mRNA. J Biol Chem 259:14301-14308.

Zhou Y, Dorsa DM (1994) Rapid effects of estrogen on the phosphorylation of the CAMP response element binding protein (CREB) in the rat brain. Soc Neurosci Abstr 20:92. 